\title{
Influence of Temperature, Inoculation Interval, and Dosage on Biofumigation with Muscodor albus to Control Postharvest Gray Mold on Grapes
}

\author{
F. Mlikota Gabler, Institute for Adriatic Crops, Put Duilova 11, 21000 Split, Croatia; R. Fassel, PACE International, \\ LLC, Visalia, CA 93291; J. Mercier, AgraQuest Inc., Davis, CA 95616; and J. L. Smilanick, United States Depart- \\ ment of Agriculture-Agricultural Research Service, San Joaquin Valley Agricultural Sciences Center, Parlier, CA \\ 93648
}

\begin{abstract}
Mlikota Gabler, F., Fassel, R., Mercier, J., and Smilanick, J. L. 2006. Influence of temperature, inoculation interval, and dosage on biofumigation with Muscodor albus to control postharvest gray mold on grapes. Plant Dis. 90:1019-1025.

Control of postharvest gray mold, caused by Botrytis cinerea, on Thompson Seedless grape by biofumigation with a rye grain formulation of Muscodor albus, a fungus that produces volatiles lethal to many microorganisms, was evaluated. The influences of temperature, biofumigant dosage, and interval between inoculation and treatment on disease incidence and severity on detached single berries were assessed. When biofumigation began within $24 \mathrm{~h}$ after inoculation, higher M. albus dosages ( $\geq 50 \mathrm{~g}$ of the M. albus grain formulation per kilogram of grapes at $20^{\circ} \mathrm{C}$ or $100 \mathrm{~g} / \mathrm{kg}$ at $5^{\circ} \mathrm{C}$ ) stopped infections and control persisted after M. albus removal. Biofumigation was more effective at 20 than $5^{\circ} \mathrm{C}$. Among inoculated clusters inside clamshell boxes incubated for 7 days at $15^{\circ} \mathrm{C}$, gray mold incidence was reduced from $20.2 \%$ among untreated grape fruit to less than $1 \%$, when $\geq 5 \mathrm{~g}$ of the formulation per kilogram of grapes was added. Among grape berries commercially packaged in ventilated polyethylene cluster bags incubated for 7 days at $15^{\circ} \mathrm{C}$, gray mold incidence was $40.5 \%$ among untreated fruit and 11.1 or $6.7 \%$ when the formulation at 5 or $20 \mathrm{~g} / \mathrm{kg}$, respectively, had been added. In the same packaging, among grape berries incubated for 28 days at $0.5^{\circ} \mathrm{C}$, gray mold incidence was $42.8 \%$ among untreated fruit and 4.8 or $4.0 \%$ when the formulation at 5 or $10 \mathrm{~g} / \mathrm{kg}$, respectively, had been added. Lower dosages $(\leq 20 \mathrm{~g} / \mathrm{kg})$ suppressed disease development while $M$. albus was present; however, after their removal, $B$. cinerea resumed growth and gray mold incidence increased. Placement of $M$. albus inside grape packages significantly controlled gray mold and may be a feasible approach to manage postharvest decay of table grape.
\end{abstract}

Gray mold, caused by Botrytis cinerea Pers., causes pre- and postharvest decay of table grapes. $B$. cinerea is especially troublesome because of its rapid growth rate and ability to spread among berries even at cold temperatures $\left(-0.5^{\circ} \mathrm{C}\right)$. Infections that cause postharvest losses can originate from spores on the surface of the berries, microscopic latent infections that occur before harvest during the growing season, or infection of mechanical wounds $(10,11)$. The fungus produces abundant aerial mycelium which spreads from infected to healthy berries, so that an uncontrolled infection from a single berry can spread to an entire package of grape berries. Postharvest gray mold usually is controlled by sulfur diox-

Corresponding author: F. Mlikota Gabler E-mail: gabe@sti.net

Current address of F. Mlikota Gabler: USDA-ARS San Joaquin Valley Agricultural Sciences Center, 9611 South Riverbend Ave, Parlier, CA 93648.

Accepted for publication 12 March 2006.

DOI: 10.1094/PD-90-1019

This article is in the public domain and not copyrightable. It may be freely reprinted with customary crediting of the source. The American Phytopathological Society, 2006. ide fumigation during initial forced-air cooling of the grape berries, followed by 2- to 6-h-long weekly fumigation during cold storage (17). In export packages, sulfur dioxide generator sheets are used, which continuously emit a low concentration of gas within the packages $(1,11)$.

Sulfur dioxide fumigation effectively controls gray mold, but bleaching injury to berries, particularly among those detached from the cluster rachis, and injury to the rachis itself occur among commercially stored grapes (9). After fumigation with sulfur dioxide, grape berries become more susceptible to subsequent infections by $B$. cinerea (30) that can occur during transportation and marketing. Although the tolerance for sulfite residues $(10 \mu \mathrm{g} / \mathrm{g})$ is rarely exceeded in commercial practice (4), excessive residues of sulfur dioxide can occur when it accumulates in wounded or detached berries (28). Also, sulfur dioxide is not accepted for organic grapes under current certification rules, and some regulatory agencies do not allow the discharge of sulfur dioxide to the air after fumigation.

Because of the issues associated with sulfite residues, sulfur dioxide emissions, and sulfur dioxide's negative impact on grape quality, alternative strategies to con- trol gray mold are needed that are safe, effective, and economical $(1,15,16,21,23)$. Alternatives to sulfur dioxide for control of postharvest gray mold include near-harvest ethanol or biological control agent applications $(11,15)$ and postharvest immersion of grapes in bicarbonates, chlorine, ethanol, or heated water $(14,16,21,23)$. However, methods requiring additional postharvest processing and handling increase costs and could alter the appearance of the berries or cause detachment of berries from the cluster rachis. Altering the orientation of the wax platelets on the surface of the berries by rubbing caused by excessive handling can destroy the bloom, which is the effect of light reflected and diffused by the overlapping wax platelets. This gives the cuticle a shine rather than the desirable luster effect (24). Alternatives requiring additional processing are unlikely to be implemented by California table grape growers, who normally pack their fruit into commercial packages in vineyards (9). The main advantage of fumigation to control postharvest decay compared with other approaches is that it does not require processing or manual handling of the grapes. Most grape storage facilities in California are designed for sulfur dioxide fumigation and use it routinely. A number of alternatives, including fumigants $(5,22,25-$ 27,32,33) and controlled atmospheres $(7,8)$, have been investigated for the control of postharvest decay of table grapes with some success. A novel alternative for controlling postharvest decay is biological fumigation, or biofumigation, with the fungus Muscodor albus Worapong, Strobel, and Hess $(18,20)$. M. albus, which was isolated from a cinnamon tree in Honduras, is a non-spore-producing fungus of the family Xylariaceae. The volatiles produced by $M$. albus, a mixture of low molecular weight compounds, are biocidal or biostatic to a broad variety of microorganisms (29,31), including Botrytis cinerea, Geotrichum citri-aurantii, G. candidum, Monilinia fructicola, Penicillium digitatum, and $P$. expansum $(18,20)$, and controlled brown rot of peach (18), gray mold and blue mold of apple (18), and green mold and sour rot of lemon (20). Isobutyric acid emission was closely associated with antifungal activity at both 4 and $21^{\circ} \mathrm{C}$ when Muscodor albus had been grown on a rye grain substrate (13). A preliminary 
report (19) also indicated that $M$. albus could control postharvest gray mold of table grapes at temperatures encountered during commercial storage $\left(-0.5\right.$ to $\left.1^{\circ} \mathrm{C}\right)$, transportation $\left(2\right.$ to $\left.5^{\circ} \mathrm{C}\right)$, and marketing (15 to $\left.20^{\circ} \mathrm{C}\right)(17)$. In $2004, M$. albus was submitted to the United States Environmental Protection Agency for registration to control postharvest diseases of food and nonfood crops, and to control preplant diseases of seeds, bulbs, and tubers (2).

Sulfur dioxide and other fumigant gases that are applied externally must penetrate into the grape packages to be effective. Luvisi et al. (17) reported that some types of table grape packaging impeded sulfur dioxide penetration more than others, although commercial packages in use today are designed to facilitate penetration of sulfur dioxide and cooling air $(9,17)$. One approach to avoid issues associated with the penetration of fumigants applied externally is to place the biofumigant $M$. albus formulation directly inside the grape packages to control postharvest gray mold on grape. Conceivably placed inside packages in the vineyard at harvest, it would provide a continuous release of volatiles during storage or marketing of grape berries and additional berry handling would not be required.

The objective of this study was to evaluate the effectiveness of biofumigation with $M$. albus to control postharvest gray mold of table grapes under environmental conditions that simulate those currently in commercial practice. In particular, the effects of temperature, time between the inoculation and fumigation, biofumigant rye grain formulation dosage, and packaging type on decay control were evaluated. Our approach included tests of continuous biofumigation with a rye grain culture of $M$. albus in standard commercial packages.

\section{MATERIALS AND METHODS}

Fruit. All experiments were conducted with Thompson Seedless grapes obtained from a commercial cold storage facility in Fresno County, California. The grape berries were harvested approximately 2 weeks before use and were of high quality (USDA No. 1 grade) and free of defects and decay. The grapes contained about $18 \%$ soluble solids, as determined by a refractometer. Soluble solids are composed primarily of fruit sugars and this concentration indicated typical commercial maturity (24).

Inoculum preparation. A $B$. cinerea isolate from grape (isolate 1440 obtained from T. J. Michailides, University of California-Davis, Parlier) was grown on potato dextrose agar for 2 weeks at $23^{\circ} \mathrm{C}$. Spores were dislodged from the colony surface with a glass rod after the addition of a small volume of sterile water with $0.05 \%$ (wt/vol) Triton X-100 surfactant. The spore suspension was filtered through four layers of cheesecloth and diluted with sterile water to an absorbance of 0.25 at $425 \mathrm{~nm}$ as determined by a spectrophotometer. This density contained $1 \times 10^{6}$ conidia/ml and was diluted with sterile deionized water to obtain the desired spore concentrations.

Biofumigant. $M$. albus formulation consisted of rye grain colonized with $M$. albus strain 620 was grown according to Mercier and Jiménez (18). The grain culture was air dried at room temperature and stored at $-8^{\circ} \mathrm{C}$ prior to use. The desiccated $M$. albus rye grain culture was activated by adding an equal weight of deionized water 2 to $3 \mathrm{~h}$ prior to use (13). In all experiments, $M$. albus was placed in an open-top plastic container and was never in direct contact with grape berries.

The effect of temperature, interval between inoculation and biofumigation, and $M$. albus formulation dosage on postharvest gray mold on detached grape berries. Two temperatures (20 and $\left.5^{\circ} \mathrm{C}\right)$, three intervals between inoculation and biofumigation $(3,24$, or $48 \mathrm{~h})$, and three $M$. albus rye grain formulation dosages $(0,50$, and $100 \mathrm{~g}$ of formulation per kilogram of grapes) were tested. Decay was evaluated immediately after incubation with $M$. albus and again after M. albus was removed and the berries had been incubated for an additional 3 days at $20^{\circ} \mathrm{C}$. The additional 3 days provided sufficient time to allow the expression of gray mold symptoms on berries that were infected at the time of inoculation, but this period was too brief for the development of visible symptoms from new infections that might have occurred during the first examination of the grapes. The incubation temperature of $20^{\circ} \mathrm{C}$ was chosen to simulate the temperature that occurs during marketing of grapes, whereas the incubation temperature of $5^{\circ} \mathrm{C}$ was chosen to simulate the temperature that occurs during storage and transportation. Berries were cut from the cluster rachis with their pedicels intact and inoculated. A suspension $(90 \mathrm{ml})$ containing $B$. cinerea at $1 \times 10^{5}$ conidia $/ \mathrm{ml}$ was applied 3, 24, or $48 \mathrm{~h}$ before treatment to the surface of about 1,800 detached berries using an air-brush sprayer. Inoculated berries were incubated at $20^{\circ} \mathrm{C}$ in a covered plastic box until treated. Three replicates of 50 single berries each were used for each of the treatments. Berries of each replicate were individually arranged on a metal rack inside a 9-liter-capacity plastic box humidified with paper tissue soaked with $40 \mathrm{ml}$ of water on the bottom of each box. A container with 10 or $20 \mathrm{~g}$ of activated $M$. albus grain formulation (equivalent to 50 or $100 \mathrm{~g}$ of M. albus grain formulation per kilogram of fruit) was placed beneath the rack with grape berries. The control contained no M. albus formulation. The boxes were arranged randomly within an environmental room. After 7 days at $20^{\circ} \mathrm{C}$ or 20 days at $5^{\circ} \mathrm{C}$, when about $50 \%$ of control berries had developed gray mold, gray mold incidence and severity were assessed. The amount and appearance of $M$. albus mycelium present on the rye grain formulation at the end of incubation also was observed. The experiment was done twice.

The effect of temperature, M. albus formulation dosage, and type of packaging on postharvest gray mold of grape clusters. Grape clusters were divided into small clusters of approximately $100 \mathrm{~g}$ each and randomized so that a portion of each cluster was represented in each treatment. Approximately $300 \mathrm{ml}$ of $10^{5}$ conidia $/ \mathrm{ml}$ was sprayed over about $50 \mathrm{~kg}$ of grape clusters. Unless stated otherwise, the grape clusters were inoculated about $3 \mathrm{~h}$ prior to treatment. M. albus grain culture was activated $2 \mathrm{~h}$ prior to treatment, as described previously.

Experiments conducted at $15^{\circ} \mathrm{C} . M$. albus formulation was placed inside a clamshell container with grape clusters. This test was done to evaluate the effectiveness of $M$. albus rye grain formulation placed inside the container with grape berries in conditions that simulated those of commercial marketing of grapes. One temperature $\left(15^{\circ} \mathrm{C}\right)$ and five $M$. albus rye grain formulation dosages $(0,5,10,20$, or $40 \mathrm{~g} / \mathrm{kg}$ of grapes) were tested. Decay was evaluated after 7 days at $15^{\circ} \mathrm{C}$. After $500 \mathrm{~g}$ of inoculated grape clusters were placed in 1.3-liter-capacity plastic clamshell boxes, a container with the M. albus grain formulation was added to each box, which then was closed. One goal was to determine minimum effective formulation dosages; therefore, the amounts were selected based on the effectiveness of the 50-g grain formulation per kilogram of grapes in prior experiments with detached berries. A single replicate consisted of one clamshell box containing $500 \mathrm{~g}$ of grapes; five replicates were prepared for each treatment. The five replicates of each treatment were placed inside a covered 27-liter plastic box. On the bottom of the 27-liter plastic box was a paper towel moistened with 100 $\mathrm{ml}$ of water. The incubation temperature of $15^{\circ} \mathrm{C}$ was chosen to simulate marketing conditions and to minimize contamination by other fungi such as Aspergillus spp. and Rhizopus spp. that can spread rapidly within clusters. The experiment was done once.

M. albus was placed outside plastic cluster bag packages of grapes in commercial boxes in the second experiment conducted at $15^{\circ} \mathrm{C}$. Cluster bags were ventilated with holes in the back and front $(2.7 \%$ vented area). This test was done to evaluate the effectiveness of $M$. albus rye grain formulation placed outside the cluster bag under conditions that simulate those of commercial marketing of table grapes. One temperature $\left(15^{\circ} \mathrm{C}\right)$ and three $M$. albus rye grain formulation dosages $(0,5$, or $20 \mathrm{~g} / \mathrm{kg}$ of grapes) were tested, and the experiment was prepared in duplicate to evaluate two 
different incubation conditions. A cup with M. albus grain formulation was placed outside (beneath) a polyethylene cluster bag that contained the inoculated grape berries. The cluster bags were arranged within a microperforated low-density plastic liner inside a corrugated fiberboard box (50 by 40 by $15 \mathrm{~cm}$ ). Each cluster bag contained approximately $800 \mathrm{~g}$ of grapes and composed one replicate. Nine replicates were prepared for each treatment and placed within the same box. To determine the persistence of $M$. albus suppression of gray mold, in a similar experiment, grapes were examined after $M$. albus had been removed, followed by additional storage. To do this, the entire experiment was prepared in duplicate. One set was examined after 7 days of incubation with $M$. albus at $15^{\circ} \mathrm{C}$; whereas, in the second set, $M$. albus was removed from the packages after 7 days at $15^{\circ} \mathrm{C}$ and then the grapes were stored for an additional 7 days at $15^{\circ} \mathrm{C}$ and examined. The number of decayed berries was recorded at each examination.

Experiments conducted at $0.5^{\circ} \mathrm{C}$. These tests were done to evaluate the effectiveness of $M$. albus rye grain formulation placed outside grape cluster bags under conditions that simulate those of commercial cold storage. Using the same packaging as in the previous experiment, one temperature $\left(0.5^{\circ} \mathrm{C}\right)$ and three $M . a l$ bus rye grain formulation dosages $(0,5$, or $10 \mathrm{~g} / \mathrm{kg}$ of grapes) were tested, and the experiment was prepared in duplicate to evaluate two different incubation conditions. Incubation conditions were 28 days at $0.5^{\circ} \mathrm{C}$ and 28 days at $0.5^{\circ} \mathrm{C}$ plus an additional 2 days at $20^{\circ} \mathrm{C}$. The additional two days at $20^{\circ} \mathrm{C}$ facilitated the expression of gray mold symptoms on the infected berries. Grapes were arranged as in the prior experiment with grape clusters, with $M$. albus placed beneath each cluster bag. The grape clusters were inoculated $15 \mathrm{~h}$ before treatment. Four replicates were prepared; each replicate consisted of one box that contained nine cluster bags with approximately $800 \mathrm{~g}$ of grapes each. The first set was examined after 28 days of incubation with $M$. albus at $0.5^{\circ} \mathrm{C}$. In the second set, $M$. albus was removed from the packages after 28 days at $0.5^{\circ} \mathrm{C}$; the grapes then were stored for an additional 2 days at $20^{\circ} \mathrm{C}$ and examined. This experiment was done once.

An identical experiment was conducted that also included a comparison of the effectiveness of sulfur dioxide to that of biofumigation with $M$. albus. The added treatment was one sulfur dioxide generator pad (PROEM Slow Release Grape Guard; Embalajes Proem Ltd., Santiago, Chile) placed on the top of grape cluster bags. The cluster bags were arranged within a microperforated low-density plastic liner inside a corrugated fiberboard box (50 by 40 by $15 \mathrm{~cm}$ ). In treatments that included M. albus, a container with 0,5 , or $10 \mathrm{~g}$ of
M. albus formulation per kilogram of grapes was placed beneath each cluster bag. Four replicates were prepared; each replicate consisted of one box that contained nine cluster bags with approximately $800 \mathrm{~g}$ of grapes each. The first set was examined after 28 days of incubation with $M$. albus at $0.5^{\circ} \mathrm{C}$. In the second set, $M$. albus was removed from the packages after 28 days at $0.5^{\circ} \mathrm{C}$; the grapes then were stored for an additional 2 days at $20^{\circ} \mathrm{C}$ and examined. This experiment was done once.

Decay assessment. After incubation, all of the berries within a treatment were examined and the total number of decayed berries recorded. During this examination, the appearance of the rachis and berries of the clusters was observed.

Gray mold incidence, which is the percentage of infected berries, was calculated. In the experiments with single detached berries, disease severity was assessed according to the following empirical scale: 0 $=$ no lesions present; $1=$ one lesion 2 to 3 $\mathrm{mm}$ in diameter was present or 1 to $5 \%$ of the berry was infected; $2=$ one lesion $\leq 10$ $\mathrm{mm}$ in diameter was present or 10 to $25 \%$ of the berry was infected; $3=$ several lesions were present or 25 to $50 \%$ of the berry surface was infected, no sporulation was present; $4=26$ to $50 \%$ of the berry surface was infected and sporulation was present; and $5=$ more than $50 \%$ of the berry surface was infected and sporulation was present. A disease severity index (DSI) was calculated using a formula reported by Cober et al. (6): DSI = [(sum of individual berry ratings) $/ 5$ (number of berries rated)] $\times 100$.

This results in a DSI of 0 where no berries were rated as infected and a DSI of 100 when $100 \%$ of the surfaces of the berries examined were infected.

Statistical analysis. During incubation, grape packages were arranged randomly in environmental rooms. The incidences of gray mold and DSIs were analyzed by an analysis of variance, followed by Fisher's protected least significant difference $(P \leq$

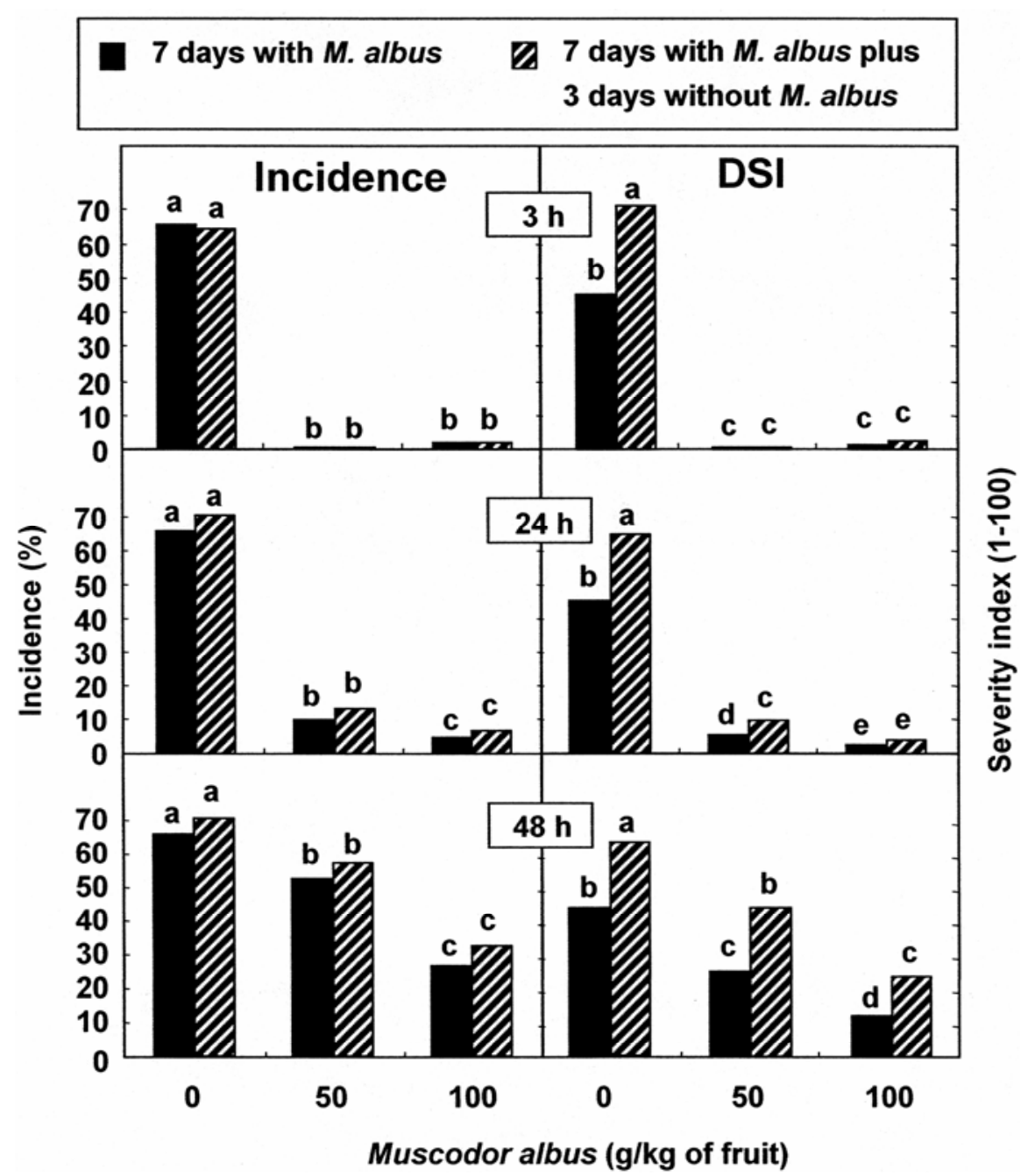

Fig. 1. Gray mold incidence and disease severity index (DSI) on single detached Thompson Seedless berries after biofumigation with Muscodor albus for 7 days at $20^{\circ} \mathrm{C}$ and additional incubation for 3 days at $20^{\circ} \mathrm{C}$ without $M$. albus presence. Berries were exposed to M. albus beginning 3, 24, or $48 \mathrm{~h}$ after inoculation with $B$. cinerea. Each column is the mean of three replicates of 50 berries. Within each panel, unlike letters indicate significant differences according to Fisher's protected least significant difference $(P=0.05)$. 
0.05) to separate means (SuperANOVA; Abacus Concepts, Inc., Berkeley, CA). Homogeneity of variances was tested using Levene's test (SPSS Inc., Chicago). An angular transformation (arcsine of the square root of the proportion of infected berries) was applied to improve homogeneity of variances if needed. Actual values are presented.

\section{RESULTS}

Biofumigation of single detached berries. Continuous biofumigation of detached berries with $M$. albus for 7 days at $20^{\circ} \mathrm{C}$ effectively reduced gray mold incidence and severity when biofumigation began $24 \mathrm{~h}$ or less after inoculation with $B$. cinerea (Fig. 1). When detached berries were exposed to $M$. albus volatiles $3 \mathrm{~h}$ after inoculation, gray mold incidence after 7 days of storage at $20^{\circ} \mathrm{C}$ was $65.8,0.8$, or $2.5 \%$ with 0,50 , or $100 \mathrm{~g}$, respectively, of $M$. albus rye grain formulation per kilogram of grapes, and did not increase after an additional incubation of 3 days without the presence of $M$. albus. Biofumigation with $M$. albus controlled gray mold incidence less effectively when the interval between inoculation and treatment was increased to $48 \mathrm{~h}$. Gray mold severity was greatly reduced when berries were exposed to $M$. albus up to $24 \mathrm{~h}$ after inoculation (Fig. 1). When the interval between inoculation and treatment was increased to $48 \mathrm{~h}$, disease severity was higher, and it increased after additional incubation of 3 days without the presence of $M$. albus. When the interval between inoculation and biofumigation was 24 or $48 \mathrm{~h}, 100 \mathrm{~g}$ of $M$. albus formulation per kilogram of grapes was the most effective treatment to control disease severity. Most of the $B$. cinerea conidia that were exposed to the $M$. albus formulation at 50 or $100 \mathrm{~g} / \mathrm{kg}$ of grapes within 3 to $24 \mathrm{~h}$ after inoculation were no longer viable after 7 days at $20^{\circ} \mathrm{C}$, because no new infections developed after $M$. albus was removed and the berries were incubated an additional 3 days at $20^{\circ} \mathrm{C}$. Dosages and intervals between inoculation and biofumigation significantly influenced gray mold incidence, whereas evaluations within treatments were not different from each other (Table 1). Interaction between the dosage and intervals between inoculation and biofumigation was significant. Dosages, intervals between inoculation and biofumigation, and evaluations all significantly influenced severity, and interactions among these factors were significant (Table 1).

Biofumigation of detached berries with M. albus for 20 days at $5^{\circ} \mathrm{C}$ effectively reduced gray mold incidence and disease severity up to $24 \mathrm{~h}$ after inoculation with B. cinerea (Fig. 2). When detached berries were exposed to $M$. albus volatiles $3 \mathrm{~h}$ after they were inoculated, gray mold incidence after 20 days of storage at $5^{\circ} \mathrm{C}$ was $45.8,10.8$, and $4.2 \%$ with 0,50 , or $100 \mathrm{~g}$ of $M$. albus formulation, respectively, per kilogram of grapes (Fig. 2). When the interval between inoculation and treatment was increased to $24 \mathrm{~h}, 100 \mathrm{~g}$ of $M$. albus formulation per kilogram of grapes was significantly better in reducing gray mold incidence and disease severity than $50 \mathrm{~g}$. After an additional incubation of 3 days at $20^{\circ} \mathrm{C}$ without the presence of $M$. albus, both gray mold incidence and disease severity increased after most treatments. Visually, the $M$. albus mycelium that developed on rye grain by the end of storage period at $5^{\circ} \mathrm{C}$ was less abundant than at $20^{\circ} \mathrm{C}$. Dosages, intervals between inoculation and biofumigation, and evaluations all significantly influenced gray mold incidence (Table 1). Interaction between the dosage and the interval between inoculation and biofumigation was significant Interaction between the dosage and evaluation was significant. Dosages, intervals between inoculation and biofumigation, and evaluations all significantly influenced severity (Table 1). Interaction between the dosage and the interval between inoculation and biofumigation was significant. Interaction between the dosage and evaluation was significant.

Biofumigation of grape clusters. Postharvest gray mold incidence on inoculated grape clusters was less than $1 \%$ when clusters were incubated with $M$. albus at $\geq 5 \mathrm{~g}$ of $M$. albus rye grain formulation per kilogram of grapes inside a closed clamshell container for 7 days at $15^{\circ} \mathrm{C}$ (Fig. 3). No visible injuries to the fruit were observed after exposure to $M$. albus volatiles.

When inoculated grape clusters were fumigated for 7 days at $15^{\circ} \mathrm{C}$ with $M$. albus placed outside cluster bags, the average gray mold incidence was $40.5,11.1$, and $6.7 \%$ with 0,5 , or $20 \mathrm{~g}$ of $M$. albus formulation, respectively, per kilogram of grapes (Fig. 4). When M. albus was removed from the package, and grape clusters were incubated for an additional 7 days at $15^{\circ} \mathrm{C}$, the average gray mold incidence increased, and of $20 \mathrm{~g}$ of $M$. albus formulation controlled gray mold more effectively than $5 \mathrm{~g} / \mathrm{kg}$ of grape clusters.

When inoculated grape clusters were fumigated for 28 days at $0.5^{\circ} \mathrm{C}$ with $M$. albus placed outside cluster bags, average gray mold incidence was significantly reduced with 5 or $10 \mathrm{~g}$ of $M$. albus rye grain formulation per kilogram of grapes (Fig. 5). When M. albus was removed from the package after 28 days of incubation at $0.5^{\circ} \mathrm{C}$, and grape clusters were incubated for an additional 2 days at $20^{\circ} \mathrm{C}$, the average gray mold incidence increased. Bio-

Table 1. Analysis of variance of experiments conducted to control gray mold on Botrytis cinerea-inoculated single detached berries by biofumigation with rye grain formulation of Muscodor albus ${ }^{\mathrm{a}}$

\begin{tabular}{|c|c|c|c|c|c|c|c|}
\hline \multirow[b]{2}{*}{ Source } & \multirow[b]{2}{*}{ df } & \multicolumn{3}{|c|}{ Incidence } & \multicolumn{3}{|c|}{ Severity } \\
\hline & & MS & $\mathbf{F}$ & $P$ & MS & $\mathbf{F}$ & $P$ \\
\hline \multicolumn{8}{|c|}{ Incubated for 7 days at $20^{\circ} \mathrm{C}$} \\
\hline Dosage (D) & 2 & 533.640 & 360.572 & 0.0001 & 0.322 & 229.968 & 0.0001 \\
\hline Inoculation interval (I) & 2 & $2,581.155$ & 123.538 & 0.0001 & 5.684 & $4,058.917$ & 0.0001 \\
\hline Evaluation (E) & 1 & 70.927 & 3.395 & 0.0737 & 35.693 & $25,490.155$ & 0.0001 \\
\hline $\mathrm{D} \times \mathrm{I}$ & 4 & 786.595 & 37.648 & 0.0001 & 0.023 & 16.174 & 0.0001 \\
\hline $\mathrm{I} \times \mathrm{E}$ & 2 & 5.873 & 0.281 & 0.7566 & 3.460 & $2,470.727$ & 0.0001 \\
\hline $\mathrm{D} \times \mathrm{E}$ & 2 & 2.253 & 0.108 & 0.8981 & 0.322 & 229.968 & 0.0001 \\
\hline $\mathrm{D} \times \mathrm{I} \times \mathrm{E}$ & 4 & 1.972 & 0.094 & 0.9836 & 0.023 & 16.174 & 0.0001 \\
\hline Residual & 36 & 20.894 & $\ldots$ & $\ldots$ & 0.001 & $\ldots$ & $\ldots$ \\
\hline \multicolumn{8}{|c|}{ Incubated for 20 days at $5^{\circ} \mathrm{C}$} \\
\hline $\mathrm{D}$ & 2 & $5,084.795$ & 216.387 & 0.0001 & 0.573 & 156.361 & 0.0001 \\
\hline I & 2 & 601.192 & 25.584 & 0.0001 & 0.114 & 31.100 & 0.0001 \\
\hline $\mathrm{E}$ & 1 & $1,448.966$ & 61.662 & 0.0001 & 0.446 & 121.881 & 0.0001 \\
\hline $\mathrm{D} \times \mathrm{I}$ & 4 & 315.756 & 13.437 & 0.0001 & 0.044 & 12.040 & 0.0001 \\
\hline $\mathrm{I} \times \mathrm{E}$ & 2 & 29.358 & 1.249 & 0.2988 & 0.002 & 0.609 & 0.5496 \\
\hline $\mathrm{D} \times \mathrm{E}$ & 2 & 264.180 & 11.242 & 0.0002 & 0.041 & 11.133 & 0.0002 \\
\hline $\mathrm{D} \times \mathrm{I} \times \mathrm{E}$ & 4 & 8.042 & 0.342 & 0.8476 & 0.001 & 0.281 & 0.8883 \\
\hline Residual & 36 & 23.499 & $\ldots$ & $\ldots$ & 0.004 & $\ldots$ & $\ldots$ \\
\hline
\end{tabular}

${ }^{a}$ Two temperatures $\left(20\right.$ and $\left.5^{\circ} \mathrm{C}\right)$, three intervals between inoculation and biofumigation (beginning 3, 24, or $48 \mathrm{~h}$ after inoculation), and three $M$. albus rye grain formulation dosages $(0,50$, and $100 \mathrm{~g}$ of formulation per kilogram of grapes) were tested. Evaluation was done immediately after incubation with $M$. albus and again after $M$. albus was removed and the berries were incubated for an additional 3 days at $20^{\circ} \mathrm{C}$. 
fumigation with $M$. albus was less effective in the second experiment (Fig. 5B), although it was superior to the treatment with the sulfur dioxide pad.

Gray mold incidence was lower immediately after incubation with 5 or $20 \mathrm{~g}$ of $M$. albus formulation per kilogram of grape clusters at $15^{\circ} \mathrm{C}$ for 7 days, or with 5 or $10 \mathrm{~g} / \mathrm{kg}$ of grapes at $0.5^{\circ} \mathrm{C}$ for 28 days. They increased when fruit was additionally incubated without $M$. albus. Volatiles of $M$. albus significantly inhibited $B$. cinerea on grape berries, but the fungus was not eradicated.

\section{DISCUSSION}

Continuous biofumigation of table grapes with a rye grain formulation of $M$. albus located within packages significantly controlled postharvest gray mold. M. albus was most effective in tests with detached single berries fumigated with 50 or $100 \mathrm{~g}$ of formulation per kilogram of grapes up to $24 \mathrm{~h}$ after inoculation, where it apparently inactivated $B$. cinerea conidia. Although our tests were not designed to assess grape quality, we did not observe any injury to the tested Thompson Seedless grapes.

M. albus more effectively controlled gray mold at 20 than at $5^{\circ} \mathrm{C}$. This was more evident when the M. albus formulation at $50 \mathrm{~g} / \mathrm{kg}$ of grapes was used rather than when $100 \mathrm{~g} / \mathrm{kg}$ was used, because the higher dosage was equally effective at both temperatures. Freitas et al. (12) reported that exposure of tomato inoculated with $B$. cinerea to $M$. albus volatiles at $22^{\circ} \mathrm{C}$ prevented infection after $4 \mathrm{~h}$ of fumigation whereas, at $15^{\circ} \mathrm{C}$, the same level of control required a 24-h exposure. Lower concentrations of $M$. albus volatiles usually were measured at $4^{\circ} \mathrm{C}$ rather than at ambient
7 days with $M$. albus

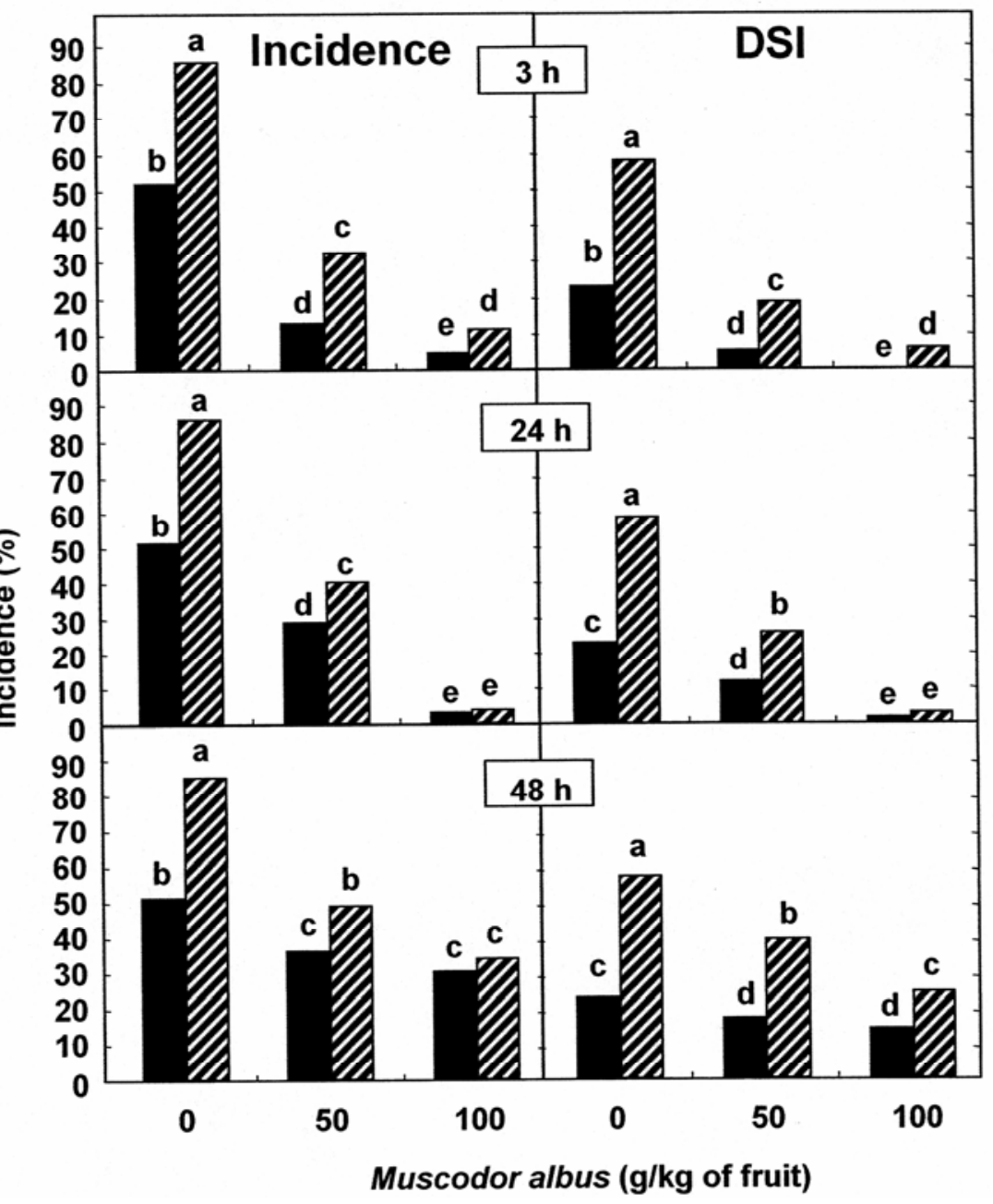

Fig. 2. Gray mold incidence and disease severity index (DSI) on single detached Thompson Seedless berries after biofumigation with Muscodor albus for 20 days at $5^{\circ} \mathrm{C}$ and additional incubation for 3 days at $20^{\circ} \mathrm{C}$ without $M$. albus presence. Berries were exposed to M. albus beginning 3, 24, or $48 \mathrm{~h}$ after inoculation with $B$. cinerea. Each column is the mean of three replicates of 50 berries. Within each panel, unlike letters indicate significant differences according to Fisher's protected least significant difference $(P=0.05)$. room temperature $(13,18)$. It is likely that $B$. cinerea was less affected at lower temperatures in our work because the amount of the volatiles produced by lower dosages of $M$. albus was insufficient to kill the pathogen. In the test conducted at $5^{\circ} \mathrm{C}$ with detached single berries, only the higher dosage of $100 \mathrm{~g}$ of $M$. albus formulation per kilogram of grapes generated a sufficient concentration of volatiles soon enough to control gray mold effectively. At $20^{\circ} \mathrm{C}$, both the low and high dosages controlled the disease effectively. Higher $M$. albus dosages would be needed at lower

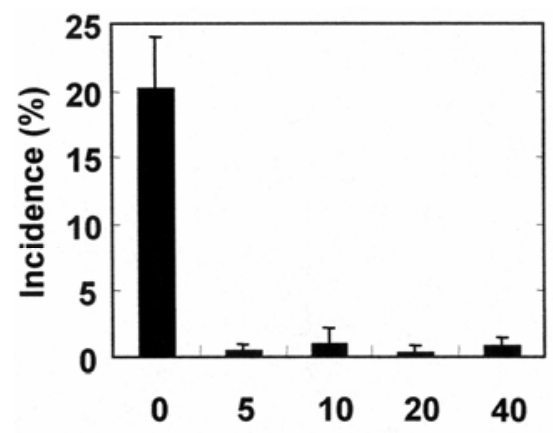

Muscodor albus (g/kg of fruit)

Fig. 3. Gray mold among inoculated grape clusters inside clamshell boxes after biofumigation with Muscodor albus. A container with $M$. albus rye grain formulation was placed inside each clamshell container and incubated for 7 days at $15^{\circ} \mathrm{C}$. Each column is the mean of five replicate clamshell boxes.
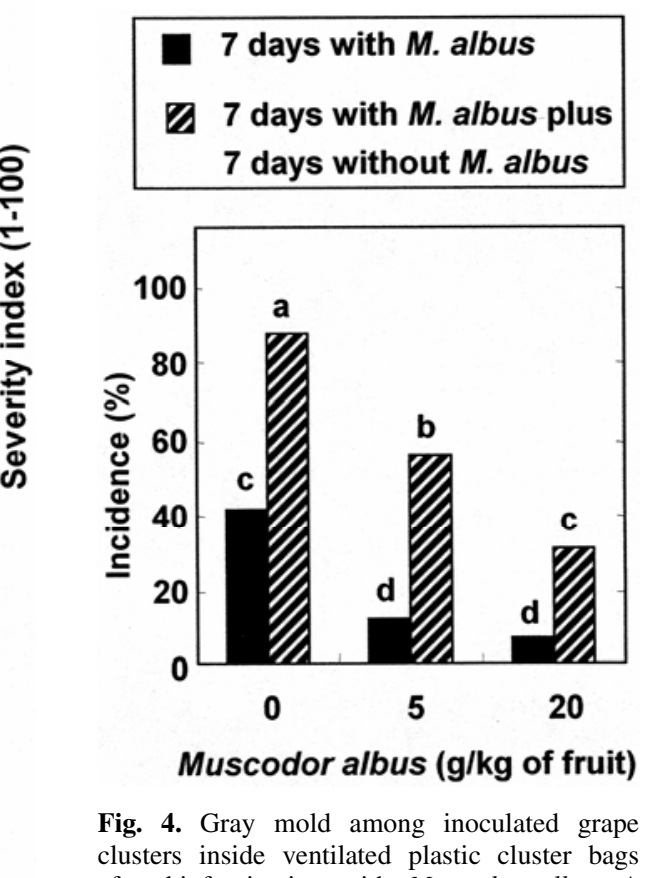

Fig. 4. Gray mold among inoculated grape clusters inside ventilated plastic cluster bags after biofumigation with Muscodor albus. A container with $M$. albus rye grain formulation was placed beneath each cluster bag within a commercial fiberboard box equipped with the microperforated liner and incubated at $15^{\circ} \mathrm{C}$. Each column is the mean of nine replicate cluster bags. Unlike letters indicate significant differences according to Fisher's protected least significant difference $(P=0.05)$. 
temperatures to generate an effective concentration of volatiles.

Within $48 \mathrm{~h}$ after inoculation, many $B$. cinerea conidia deposited on the grape berry surface germinated and grew into the host tissue, especially if wounds or pores were present (23). M. albus was not able to inactivate the pathogen deeper in the fruit tissues, but only on or near the surface, because it was significantly less effective when applied $48 \mathrm{~h}$ after inoculation. It is likely the pathogen within the berry tissue already was protected from $M$. albus volatiles when biofumigation began $48 \mathrm{~h}$ after inoculation. This delay in initiation of treatment resulted in significantly higher disease severity readings, particularly when the berries were examined after an additional 3 days of incubation without the presence of $M$. albus. Mercier and Jiménez (18) suggested that, in most cases, biofumigation of apple fruit with $M$. albus up to 24 h after inoculation with $B$. cinerea or $P$. expansum killed the pathogens in wounds rather than just inhibited them, because lesions never developed in the biofumigated fruit after $M$. albus was removed. Our findings corroborated their work, particularly with high dosages of 50 or $100 \mathrm{~g}$ of $M$. albus rye grain formulation when the interval between inoculation of the grape berries with $B$. cinerea and their exposure to $M$. albus volatiles was short $(3 \mathrm{~h})$, because control of gray mold persisted after M. albus was removed. Biofumigation of lemon fruit applied immediately after inoculation with $P$. digitatum was more effective in reducing green mold than biofumigation that began $24 \mathrm{~h}$ after inoculation (20). Mercier and Smilanick (20) also reported that biofumigation with $M$. albus of lemon fruit inoculated with $G$. citri-aurantii that began immediately after

\section{8 days at $0.5^{\circ} \mathrm{C}$}

\section{8 days at $0.5^{\circ} \mathrm{C}$ plus 2 days at $20^{\circ} \mathrm{C}$}

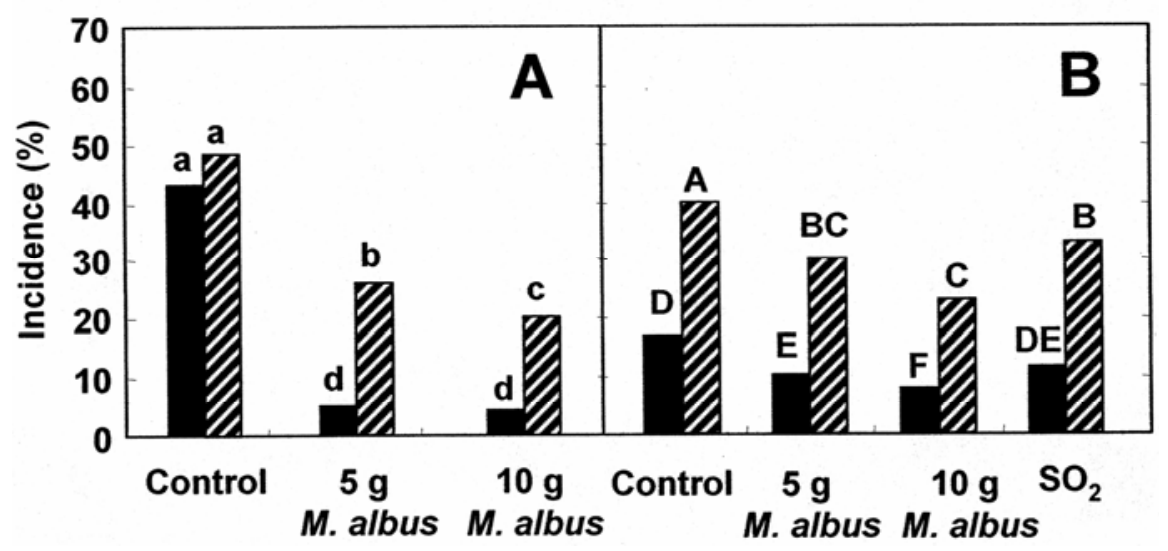

Fig. 5. Gray mold among inoculated grape clusters inside ventilated plastic cluster bags after biofumigation with Muscodor albus. A container with M. albus rye grain formulation was placed beneath each cluster bag within a commercial fiberboard box equipped with the microperforated liner and incubated at $0.5^{\circ} \mathrm{C}$. Each column is the mean of four replicate grape boxes. Within each panel, unlike letters indicate significant differences according to Fisher's protected least significant difference $(P=0.05)$.
Mercier and Smilanick (20) used a "weight of $M$. albus grain formulation per volume of space treated" to calculate the dosage for biofumigation of lemon fruit in a near-empty room. However, they suggested that, in storage rooms filled with fruit with little remaining air volume, a biofumigant:fruit biomass ratio could be a more accurate method to determine the dosage because fruit vary in surface area and possibly in their ability to bind or degrade volatiles. This approach was used in our experiments, which probably gave us a more accurate estimate of biofumigant formulation required to control gray mold on table grape than a dosage based on the container volume. It is likely that the better control of gray mold we observed among single detached berries than in those with grape clusters was due to the higher dosage used in the former experiments. Additionally, the single detached berries on wire racks were completely exposed to the volatiles, whereas exposure to the volatiles of clusters tightly packed within cluster bags may have been impaired. Mercier and Smilanick (20) reported that there was an inverse relationship between the $M$. albus dosage and the incidence of green mold among lemon fruit, indicating that disease control was directly related to the amount of biofumigant used. Furthermore, the fumigated fruit may metabolize some of the volatile and this could influence the dosage needed. Archbold et al. (3) reported that, during postharvest fumigation of strawberry, blackberry, and grape with (E)-2-hexenal, a compound with antifungal activity that is naturally produced in plant tissue, the fumigated fruit metabolized the volatile to several products. Strawberry accumulated more (E)-2-hexenal than grape or blackberry. Surface area, physiological activity, storage requirements, and postharvest diseases vary among fruit species; therefore, the exposure times and biofumigant dosages for optimal disease control may be different for each commodity.

Biofumigation of grapes with $M$. albus was effective in controlling table grape postharvest gray mold in many types of grape packages. It combines the advantages of fumigation with biological control. The fungus is never in direct contact with the commodity; therefore, there is no visible microbe residue on fruit. The postharvest use of $M$. albus in table grapes could be a very flexible approach because it is compatible with the various phases of the handling process, packaging and storage within export containers, or within the fruit packages themselves. The treatment could be applied passively by simply placing active $M$. albus formulations within packages of grapes as is now done with sulfur dioxide generator pads. Because the handling of fruit is minimal, the adverse impacts of additional handling or repackaging of the fruit required to implement some other nonfumigant postharvest 
treatments are avoided; therefore, negative impacts on berry appearance and quality from handling are minimized.

The effectiveness of biofumigation with M. albus to control postharvest gray mold of table grapes was high enough to be useful for commercial purposes and it could be implemented with current commercial packaging and practices. A more convenient container has been developed, although we did not use it in this work, that encloses the $M$. albus rye grain formulation within porous paper sheets. M. albus volatiles have a "musky" odor that declines rapidly once $M$. albus is removed. Even though we observed no negative impacts on grape quality, all of our experiments were done with the cultivar Thompson Seedless. Further evaluation of biofumigation by $M$. albus should incorporate the assessment of internal and external fruit quality, including taste evaluation, of this and other major table grape cultivars.

\section{ACKNOWLEDGMENTS}

We thank the California Table Grape Commission for partial financial support of this work and acknowledge review of the manuscript by J. Gerik and D. Margosan. All experiments were conducted at the USDA-ARS, San Joaquin Valley Agricultural Sciences Center in Parlier, CA.

\section{LITERATURE CITED}

1. Adaskaveg, J. E., Förster, H., and Sommer, N. F., 2002. Principles of postharvest pathology and management of decays of edible horticultural crops. Pages 163-195 in: Postharvest Technology of Horticultural Crops. A. A. Kader, ed. Publication 3311. University of California, Agriculture and Natural Resources, Oakland.

2. Anon. 2004. Pesticide product; registration applications. Fed. Regist. 69:19845-19847.

3. Archbold, D. D., Hamilton-Kemp, T. R., Barth, M. M., and Langlois, B. E. 1997. Identifying natural volatile compounds that control gray mold (Botrytis cinerea) during postharvest storage of strawberry, blackberry and grape. J. Agric. Food. Chem. 45:4032:4037.

4. Austin, A. K., Clay, W., Phimphiwong, S., Smilanick, J. L., and Henson, J. D. 1997. Patterns of sulfite residues in grapes during three months of repeated sulfur dioxide fumigations. Am. J. Enol. Vitic. 48:121-124.

5. Avissar, I., and Pessis, E. 1991. The control of postharvest decay in table grapes using acetaldehyde vapours. Ann. Appl. Biol. 118:229-237.

6. Cober, E. R., Rioux, S., Rajcan, I., Donaldson, P. A., and Simmonds, D. H. 2003. Partial resistance to white mold in a transgenic soybean line. Crop Sci. 43:92-95.

7. Crisosto, C. H., Garner, D., and Crisosto, G.
2002. Carbon dioxide-enriched atmospheres during cold storage limit losses from Botrytis but accelerate rachis browning of 'Redglobe' table grape. Postharvest Biol. Technol. 26:181189.

8. Crisosto, C. H., Garner, D., and Crisosto, G. 2002. High carbon dioxide atmospheres affect stored 'Thompson Seedless' table grapes. Hortscience 37:1074-1078.

9. Crisosto, C. H., and Mitchell, F. G. 2002. Postharvest handling systems: small fruits. I. Table grapes. Pages 357-363 in: Postharvest Technology of Horticulture Crops. A. A. Kader, ed. Publication 3311. University of California, Agriculture and Natural Resources, Oakland.

10. De Kock, P. J., and Holz, G. 1994. Application of fungicides against postharvest Botrytis cinerea bunch rot of table grapes in the Western Cape. S. Afr. J. Enol. Vitic. 15:33-40.

11. Droby, S., and Lichter, A. 2004. Post-harvest Botrytis infection: etiology, development and management. Pages 349-367 in: Botrytis: Biology, Pathology and Control. Y. Elad, B. Williamson, P. Tudzynski, and N. Delen, eds. Kluwer Academic Publishers, London.

12. Freitas, P., Suslow, T., and Mercier, J. 2005. Biofumigation with Muscodor albus for postharvest control of gray mold rot and Salmonella contamination of tomatoes. (Abstr.) Phytopathology 95:S31.

13. Jiménez, J. I., and Mercier, J. 2005. Optimization of volatile organic compound production from rye grain culture of Muscodor albus for postharvest fumigation. (Abstr.) Phytopathology 95:S48.

14. Karabulut, O. A., Mlikota Gabler, F., Mansour, M., and Smilanick, J. L. 2004. Postharvest ethanol and hot water treatments of table grapes to control gray mold. Postharvest Biol. Technol. 36:169-176.

15. Karabulut, O. A., Smilanick, J. L., Mlikota Gabler, F., Mansour, M., and Droby, S. 2003. Near-harvest applications of Metschnikowia fructicola, ethanol, and sodium bicarbonate to control postharvest diseases of grape in central California. Plant Dis. 87:1384-1389.

16. Lichter, A., Zutchy, Y., Sonego, L., Dvir, O., Kaplunov, T., Sarig, P., and Ben-Arie, R. 2002. Ethanol controls postharvest decay of table grapes. Postharvest Biol. Technol. 24:301-208.

17. Luvisi, D. A., Shorey, H. H., Smilanick, J. L., Thompson, J. F., Gump, B. H., and Knutson, J. 1992. Sulfur dioxide fumigation of table grapes. Publication 1932. Univ. Calif. Div. Agric. Sci. Oakland.

18. Mercier, J., and Jiménez, J. I. 2004. Control of fungal decay of apples and peaches by the biofumigant fungus Muscodor albus. Postharvest Biol. Technol. 31:1-8.

19. Mercier, J., and Smilanick, J. L., 2003. Control of green mold and sour rot of lemons and gray mold rot of grapes by biofumigation with Muscodor albus. (Abstr.) Phytopathology 93:S61.
20. Mercier, J., and Smilanick, J. L. 2005. Control of green mold and sour rot of stored lemon by biofumigation with Muscodor albus. Biol. Control 32:401-407.

21. Mlikota Gabler, F., and Smilanick, J. L. 2001. Postharvest control of table grape gray mold on detached berries with carbonate and bicarbonate salts and disinfectants. Am. J. Enol. Vitic. 52:12-20.

22. Mlikota Gabler, F., Smilanick, J. L., Aiyabei, J., and Mansour, M. 2002. New approaches to control postharvest gray mold (Botrytis cinerea Pers.) on table grapes using ozone and ethanol. Page 78 in: Proc. World Microbes Xth Int. Congr. Mycol. Paris.

23. Mlikota Gabler, F., Smilanick, J. L., Ghosoph, J. M., and Margosan, D. A. 2005. Impact of postharvest hot water or ethanol treatment of table grapes on gray mold incidence, quality, and ethanol content. Plant Dis. 89:309-316.

24. Nelson. 1985. Harvesting and handling California table grapes for market. Bull. 1913. Agric. Exp. Stn. Univ. Calif. Agric. Nat. Resour. Oakland.

25. Palou, L., Crisosto, C. H., Smilanick, J. L., Adaskaveg, J. E., and Zoffoli, J. P. 2002. Effects of continuous $0.3 \mathrm{ppm}$ ozone exposure on decay development and physiological responses of peaches and table grapes in cold storage. Postharvest Biol. Technol. 24:39-48.

26. Sarig, P., Zahavi, T., Zutkhi, Y., Yannai, S. Lisker N., and Ben-Arie, R. 1996. Ozone for control of post-harvest decay of table grapes caused by Rhizopus stolonifer. Physiol. Mol. Plant Pathol. 48:403-415.

27. Sholberg, P. L., and Gaunce, A. P. 1995. Fumigation of fruit with acetic acid to prevent postharvest decay. Hortscience 30:1271-1275.

28. Smilanick, J. L., Harvey, J. M., Hartsell, P. L., Hensen, D. J., Harris, C. M., Fouse, D. C., and Assemi, M. 1990. Factors influencing sulfite residues in table grapes after sulfur dioxide fumigation. Am. J. Enol. Vitic. 41:131-136.

29. Strobel, G. A., Dirkse, E., Sears, J., and Markworth, C., 2001. Volatile antimicrobials from Muscodor albus, a novel endophytic fungus. Microbiology 147:2943-2950.

30. Taylor, M. A., Watts, J. E., and Chambers, K. R. 1990. Sulphur dioxide damage as a predisposing factor to botrytis rot of table grape berries. Deciduous Fruit Grow. 40:35-41.

31. Worapong, J., Strobel, G. A., Ford, E. J., Li, J. Y., Baird, G., and Hess, W. M. 2001. Muscodor albus anam. sp. nov., an endophyte from Cinnamomum zeylanicum. Mycotaxon 79:6779.

32. Yahia, E. M., Nelson, K. E., and Kader, A. A. 1983. Postharvest quality and storage life of grapes as influenced by adding carbon monoxide to air or controlled atmospheres. J. Am. Soc. Hortic. Sci. 108:1067-1071.

33. Zoffoli, J. P., Latorre, B. A., Rodriguez, E. J., and Aldunce, P. 1999. Modified atmosphere packaging using chlorine gas generators to prevent Botrytis cinerea on table grapes. Postharvest Biol. Technol. 15:135-142. 